\title{
Further Studies on Cytostatic Activity of Alkoxymethyl Purine and Pyrimidine Acyclonucleosides
}

\author{
Hanna Modrzejewska ${ }^{\mathrm{a}}$, Marcin Dramiński ${ }^{\mathrm{b}}$, Anna Zgit-Wróblewska ${ }^{\mathrm{c}}$ and \\ Janusz Greger ${ }^{\mathrm{a}, *}$ \\ a Department of Biochemistry, Institute of Physiology and Biochemistry, Medical University \\ of Łódź, Lindleya 6, 90-131 Łódź, Poland. \\ Fax:048426782465. E-mail: tpietruc@psk 2. am. lodz.pl \\ b Department of General Chemistry, the Ludwik Rydgier Medical University of Bydgoszcz, \\ Karłowicza 24, 85-092 Bydgoszcz, Poland \\ c Department of General Chemistry, Institute of Basic Sciences, Military School of Medicine, \\ pl.Hallera 1, 90-647 Łódź, Poland \\ * Author for correspondence and reprint requests \\ Z. Naturforsch. 54c, 923-931 (1999); received March 3/June 25, 1999
}

Acyclonucleosides, Deoxynucleotide Kinases, Melanoma

\begin{abstract}
The influence of 14 acyclonucleosides ${ }^{1}$, derivatives of adenine, guanine, uracil and thymine on the phosphorylation of dAdo, dGuo, dCyd and dThd occurring in the cytosol of growing amelanotic melanoma transplanted to Syrian hamsters, as well as on inhibition of tumor growth were studied. From among the studied ACNs eight were tested earlier (Modrzejewska et al., 1996, The influence of alkoxymethyl purine and pyrimidine acyclonucleosides on growth inhibition of Kirkman-Robbins hepatoma and possible mechanism of their cytostatic activity, Z. Naturforch. 51c, 75-80); from among the newly synthesized ACNs, 1,3-N,N-diallyloxymethylthymine (AMT2), 1-N-allyloxymethyl-5,6-tetramethyleneuracil (AMUTM), and tested previously 1- $N$-allyloxymethylthymine (AMT1), administered i.p. in a dose of $0.2 \mathrm{mmol} / \mathrm{kg}$ body weight reduce the tumor mass from $0.98 \mathrm{~g}$ to $0.64 \mathrm{~g} \pm 0.11 \mathrm{~g}$ (i.e. $35 \% \pm 12 \%$ ). 48 hours after i.p. administration of the mentioned ACNs in the same dose a reduction of tumor mass is accompanied by the inhibition of dAMP, dGMP and dTMP synthesis. AMT1 inhibits dThd phosphorylation from 6.2 to 4.22; AMT2 suppresses dAdo, dGuo and dThd phosphorylation by, correspondingly, from 2.8 to 1.7 , from 10.8 to 7.5 and from 6.2 to 4.2 ; AMUTM depresses dAMP synthesis from 2.8 to 1.6 (all data: $\mu$ mol of 2 'dNMP formed per mg of protein per min. $\times$ $10^{-4}$ ). None of the 14 studied acyclonucleosides influences dCMP synthesis. In vivo, after hydration of allyloxymethyl group to hydroxypropoxymethyl residue (having $-\mathrm{CH}_{2} \mathrm{OH}$ group), AMT1, AMT2 and AMUTM undergo phosphorylation to corresponding triphosphates. Phosphorylated ACNs are not incorporated into tumor DNA, however they inhibit dAdo, dGuo and dThd incorporation into DNA. It is concluded that ACN triphosphates are not substrates for DNA polymerase but, competing with dATP dGTP and dTTP, inhibit incorporation of these 2'dNTP into DNA and, in consequence, reduce tumor growth, which is presumed to be the main mechanism of cytostatic activity of the studied ACNs.
\end{abstract}

\begin{abstract}
${ }^{1}$ Abbreviations: ACN, acyclonucleoside; dAdo, 2'-deoxyadenosine; dGuo, 2'-deoxyguanosine; dCyd, 2'-deoxycytidine; dThd, 2'-deoxythymidine; 2'dN, 2'-deoxynucleoside; 2'dNMP, 2'-deoxynucleoside-5'-monophosphate; 2'dNTP, 2'-deoxynucleoside-5'-triphosphate; AMT1, 1- $N$-allyloxymethylthymine; AMT2, 1,3-N,N-diallyloxymethylthymine; DHPMT1, 1-N-[(2',3'-dihydroxy-1'-propoxy)methyl]thymine; DHPMT2, 1-N-[(1',3'-dihydroxy-2'-propoxy)methyl]thymine; PMT, $1-N$-propoxymethylthymine; AMU, $1-N$-allyloxymethyluracil; DHPMU, $1-N-\left[\left(2^{\prime}, 3\right.\right.$ '-dihydroxy-1'-propoxy)methyl]uracil; AMUTM, 1- $N$-allyloxymethyl-5,6-tetramethyleneuracil; DHPMUTM, 1- $N$ [(2',3'-dihydroxy-1'-propoxy)methyl]-5,6-tetramethyleneuracil; DHPMUDM, 1-N-[(2',3'-dihydroxy-1'-propoxy)methyl]-5,6-dekamethyleneuracil; AMUF, $1-N$-allyloxymethyl-5-fluorouracil; AMA, 9- $N$-allyloxymethyladenine; AMG, 9- $N$-allyloxymethylguanine.
\end{abstract}

\section{Introduction}

Results presented in this paper, being part of the current studies on acyclonucleosides (ElAshry and ElKiliany, 1997; Thormar et al., 1998), resume our research on ACNs possessing potential cytostatic properties (Greger and Dramiński, 1989; Modrzejewska et al., 1994; Modrzejewska et al., 1996). The present results deal with eight previously tested and six newly synthesized alkoxymethylpyrimidine ACNs, derivatives of uracil and thymine, subjected to a study on a different biological model. ACNs tested previously (Fig. 1, compounds I,IV,V,VI,VII,XII,XIII,XIV) were in- 
vestigated on the growing Kirkman-Robbins hepatoma. Now both groups of ACNs (Fig. 1, previously tested and newly synthesized ACNs, compounds: II,III,VIII,IX,X,XI) were subjected to tests on growing amelanotic melanoma transplanted, similarly as hepatoma, to Syrian hamsters.

A mechanism of cytostatic activity of allyloxymethyl derivatives of uracil and thymine has been proposed based on the results obtained in in vivo and in vitro experiments concerning 2 'dN kinases activities present in the cytosol of a growing tumor subjected to biologically active ACNs (AMT1,AMT2, AMUTM), on phosphorylation of these ACNs and on incorporation of 2 'dN into tumor DNA.

\section{Materials and Methods}

\section{Chemicals}

$\left[{ }^{14} \mathrm{C}\right] \mathrm{dAdo},\left[{ }^{14} \mathrm{C}\right] \mathrm{dThd},\left[{ }^{32} \mathrm{P}\right] \gamma$ ATP were obtained from Amersham Corp. (Buckinghamshire, England); $\left[{ }^{14} \mathrm{C}\right] \mathrm{dCyd}$ from Sigma Chemical Company
(St. Louis MO, USA) and $\left[{ }^{14} \mathrm{C}\right] \mathrm{dGuo}$ from Ustav pro Vyzkum Vyrobu a Vyuziti Radioactive (Prague, Czechoslovakia). Unlabeled 2'dNs, 2'dNMPs, and 2'dNTPs were purchased from Sigma Chemical Company (St. Louis, USA), Aldrich Chemical Company (Milwaukee, USA) and Boehringer (Mannheim, Germany). Other reagents used were highest quality commercially available products from Fluka AG, Loba-Chemie (Vienna, Austria), Koch-Light Lab. and Polskie Odczynniki Chemiczne (Gliwice, Poland). Allyloxymethyl purine and pyrimidine ACNs were obtained as described previously (Modrzejewska et al., 1996; comp.: I,IV, V, VI, VII, XII, XIII, XIV; Fig. 1). Compounds III, VIII, IX, X ,XI (Fig. 1) were produced by oxidation of the appropriate 1$\mathrm{N}$-allyloxymethyl derivatives of heterocyclic bases. The oxidation agent was potassium chloride in the presence of osmium tetroxide. AMT2 (Fig. 1, comp. II) was obtained by condensation of 1,3$\mathrm{O}$ (trimethylsilyl)thymine with excess of chloromethylacetyl ether. Purification was performed ac-

Thymine derivatives
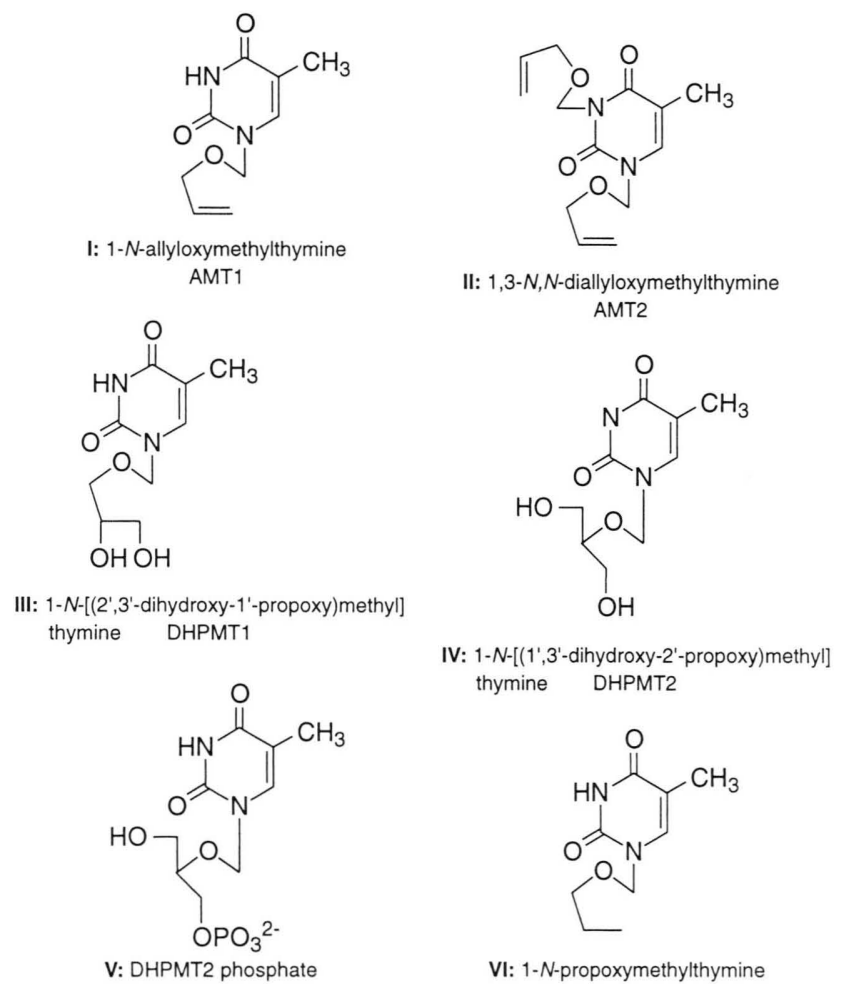

V: DHPMT2 phosphate

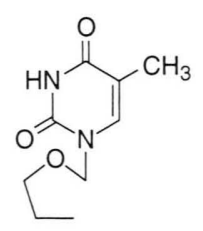

VI: 1-N-propoxymethylthymine PMT 
Uracil derivatives

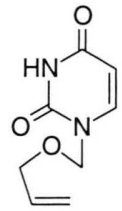

VII: $1-N$-allyloxymethyluracil AMU<smiles>C=CCOCn1c2c(c(=O)[nH]c1=O)CCCC2</smiles>

IX: 1-N-allyloxymethyl-5,6-tetramethyleneuracil AMUTM

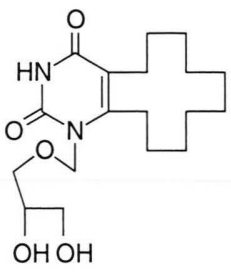

XI: $1-N-\left[\left(2^{\prime} 3^{\prime}-\right.\right.$ dihydroxy-1'-propoxy)methyl] -5,6-tetramethyleneuracil DHPMUDM
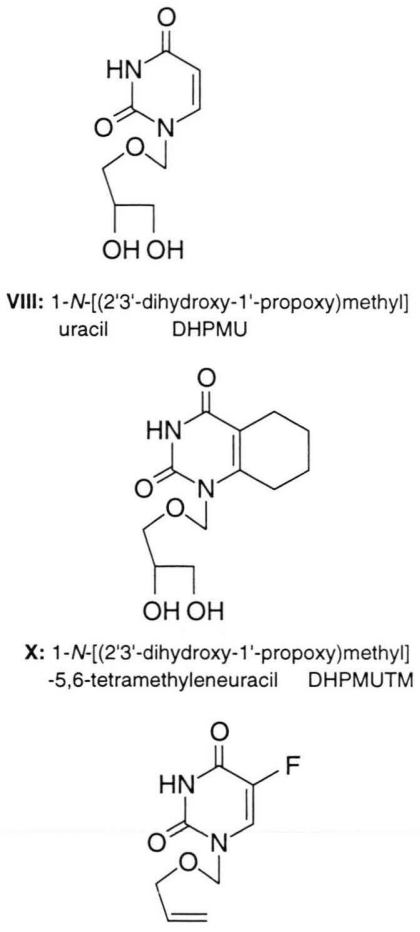
XII: $1-N$-allyloxymethyl-5-fluorouracil
AMUF
Purine derivatives

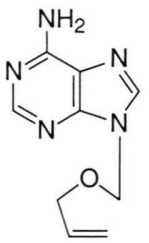

XIII: 9- $N$-allyloxymethyladenine AMA<smiles>C=CCOCn1cnc2c(=O)[nH]c(N)nc21</smiles>

XIV: 9- $N$-allyloxymethylguanine AMG
Fig. 1. Structural formulae of the investigated acyclonucleosides. cording to a procedure of Dramiński and Frass, 1981. The ACNs were checked for chromatographic homogeneity with at least two solvent systems. Analytical data are given in Table I. $\left[{ }^{14} \mathrm{C}\right] \mathrm{AMT} 1,\left[{ }^{14} \mathrm{C}\right] \mathrm{AMT} 2$ and $\left[{ }^{14} \mathrm{C}\right] \mathrm{AMUTM}$ were obtained by the same methods as unlabeled ACNs using $\left[{ }^{14} \mathrm{C}\right]$ thymine or $\left[{ }^{14} \mathrm{C}\right]$ uracil instead of unlabeled thymine or uracil (Ozierov et al., 1991; Drabikowska et al., 1987). $1 \mathrm{~cm}$ zones were scraped from the TLC silica gel plates (Merck Kiselgel $60 \mathrm{~F}, 0.2 \mathrm{~mm}$ ) and counted by a liquid scintillation counter (1600 TR Packard liquid scintillation analyzer). The ACN spots contained $\left[{ }^{14} \mathrm{C}\right]$ label only. The rest of the chromatograms had background level activity.

\section{Animals and preparation of subcellular fractions}

A group of four female Syrian hamsters (weighing 80-90 g) was used for each experiment. Amelanotic melanoma, obtained from Department of Histology, Medical University of Gdańsk, belongs to a family of melanomas transplantable to hamsters (Słomiński and Paus, 1993; Bomirski et al., 1998) and represents one of the fast growing tumors. The tumor was maintained as a subcutaneous transplant at 10 days' intervals. The most intensive growth of tumor occurred at 10-12 days after transplantation. From the 16-18 day regressive changes took place and within one week the tumor was eliminated. For the in vivo experiments, 10 days after tumor transplantation the animals were given i.p. respective ACNs $(0.2 \mathrm{mmol}$ per $\mathrm{kg}$ of body weight), $48 \mathrm{~h}$ later they were sacrificed by sectioning the cervical spinal chord, tumor was excised, homogenized at $0{ }^{\circ} \mathrm{C}$ in Potter-Elvehjem apparatus and nuclear and cytosol fractions obtained as described previously (Modrzejewska et al., 1996) were used for the experiments. In in vitro experiments, 10 days after tumor transplantation the animals were sacrificed and the cytosol obtained as above was assayed for the enzyme activity. 


\section{Chemical and enzyme assays}

2 'dN kinase activities were assayed as described previously (Greger and Dramiński, 1989). The phosphorylation of ACNs was performed under conditions matching all 2'dN kinases activities, using $0.2 \mathrm{~mm} A C N$ as a substrate and $10 \mathrm{~mm}\left[{ }^{32} \mathrm{P}\right]$ $\gamma$ ATP of $0.5 \mu \mathrm{Ci}(0.0185 \mathrm{MBq})$ per sample as phosphate donor. Phosphorylation products were separated by TLC (Modrzejewska et al., 1996) and spots corresponding to standards were counted as above (see Chemicals). DNA was isolated and $\left[{ }^{14} \mathrm{C}\right] 2$ ' $\mathrm{dN}$ or $\left[{ }^{14} \mathrm{C}\right] \mathrm{ACN}$ were assayed according to methods described by Blin and Stafford (1976), and protein by Bradford (1976). 2'dN kinase activities and ACN phosphorylation products were expressed as $\mu \mathrm{mol}$ of 2 'dNMP or ACN phosphates formed per mg of protein per min. $\times 10^{-4}$. Statistical calculations were made using Student's, FisherSnedecor tests and a Chem Windows 3 statistical computer program.

\section{Results and Discussion}

The influence of 14 ACNs on the growth of amelanotic melanoma and on 2'dN kinase activities present in the cytosol of the growing tumor were investigated. AMT1, AMT2 and AMUTM administered i.p. to animals 10 days after tumor transplantation in a dose of $0.2 \mathrm{mmol}$ per $\mathrm{kg}$ of body weight reduced the tumor weight from $0.98 \mathrm{~g}$ to $0.64 \mathrm{~g} \pm 0.11 \mathrm{~g}$, i.e. $35 \pm 12 \%$ (mean $\pm \mathrm{SD}$ for four separate experiments). Table II demonstrates the influence of AMT1, AMT2 and AMUTM on the activity of these enzymes. The above mentioned ACNs inhibit the synthesis of dTMP (AMT1, AMT2), dGMP(AMT2) and dAMP (AMT2, AMUTM) both in vivo and in vitro. This inhibition (expressed in $\mu \mathrm{mol}$ of 2 'dNMP formed per mg. of protein per min. $\times 10^{-4}$ ) was found from 5.4 to 4.0 in vitro and from 6.2 to 4.2 in vivo, i.e. $26-34 \%$ for dThd kinase, from 11.2 to 8.1 in vitro and from 10.8 to 7.5 in vivo, i.e. $28-31 \%$ for dGuo kinase and from 2.3 to 1.5 in vitro and from 2.8 to 1.6.in vivo, i.e. $35-44 \%$ for dAdo kinase. None of the 14 mentioned ACNs influences the synthesis of dCMP. No significant differences have been found in results of experiments in vivo (average inhibition of 2'dN kinases activities in experiments in vivo was $35.8 \pm 5.1 \%$, in experiments in vitro: $33.0 \pm 7.1 \%$ ), whereas the $\mathrm{K}_{\mathrm{i}}$ determined in experiments in vitro (Fig. 2) varied considerably (from $76 \mu \mathrm{M}$ for AMUTM inhibiting the synthesis of dAMP to $227 \mu \mathrm{M}$ for AMT2 inhibiting the synthesis of dGMP, see Table II). Attention should be drawn to the fact that ACNs which were the in vivo inhibitors of dGMP and dTMP synthesis in

Table I. Analytical data of newly synthesized ACN's.

\begin{tabular}{|c|c|c|c|c|c|c|c|c|c|c|c|c|c|c|}
\hline Compound & $\begin{array}{l}\text { Yield } \\
{[\%]}\end{array}$ & m.p. $\left[{ }^{\circ} \mathrm{C}\right]$ & $\begin{array}{r}\mathrm{TL} \\
\mathrm{S}_{1}\end{array}$ & $\begin{array}{l}\mathrm{C} \\
\mathrm{S}_{2}\end{array}$ & \multicolumn{2}{|c|}{$\begin{array}{c}\mathrm{UV} \\
\lambda_{\max }[\mathrm{nm}] \\
\in \times 10^{3}\end{array}$} & M & B & \multicolumn{2}{|c|}{$\begin{array}{c}\text { MS (70ev) } \\
m / z \\
{[\%]} \\
B+14\end{array}$} & B-29 & $\mathrm{B}+28$ & \multicolumn{2}{|c|}{$\begin{array}{c}{ }^{1} \mathrm{H}-\mathrm{NMR} \\
\left(\mathrm{CHCl}_{3}\right)\end{array}$} \\
\hline AMT2 & 28 & oil & 0.62 & 0.59 & $\begin{array}{r}270 \\
7.6\end{array}$ & $\begin{array}{r}270 \\
5.8\end{array}$ & $\begin{array}{r}266 \\
1.3\end{array}$ & $\begin{array}{r}125 \\
1.1\end{array}$ & $\begin{array}{r}126 \\
2.9\end{array}$ & $\begin{array}{l}130 \\
11.1\end{array}$ & $\begin{array}{l}96 \\
28.6\end{array}$ & $\begin{array}{l}153 \\
1.4\end{array}$ & 5.14 & $5.42 \mathrm{~s}$ \\
\hline DHPMT1 & 47 & $138-9$ & 0.35 & 0.63 & $\begin{array}{r}264 \\
8.2\end{array}$ & $\begin{array}{r}264 \\
6.6\end{array}$ & $\begin{array}{l}230 \\
2.0\end{array}$ & $\begin{array}{l}125 \\
2.0\end{array}$ & $\begin{array}{l}126 \\
100\end{array}$ & $\begin{array}{c}139 \\
38.4\end{array}$ & $\begin{array}{l}96 \\
55.2\end{array}$ & & $5.20 \mathrm{~d}$ & \\
\hline DHPMU & 60 & $132-4$ & 0.26 & 0.46 & $\begin{array}{l}259 \\
10.2\end{array}$ & $\begin{array}{r}259 \\
9.4\end{array}$ & $\begin{array}{r}216 \\
0.8\end{array}$ & $\begin{array}{r}111 \\
1.3\end{array}$ & $\begin{array}{c}112 \\
51.9\end{array}$ & $\begin{array}{l}125 \\
57.2\end{array}$ & $\begin{array}{r}82 \\
100\end{array}$ & & $5.22 \mathrm{~d}$ & \\
\hline DHPMUDM & 56 & $168-9$ & 0.73 & 0.88 & $\begin{array}{r}271 \\
9.3\end{array}$ & $\begin{array}{l}269 \\
7.6\end{array}$ & $\begin{array}{r}354 \\
5.4\end{array}$ & $\begin{array}{r}249 \\
4.2\end{array}$ & $\begin{array}{l}250 \\
100\end{array}$ & $\begin{array}{l}263 \\
20.5\end{array}$ & $\begin{array}{r}220 \\
6.9\end{array}$ & & $5.38 \mathrm{~s}$ & \\
\hline DHPMUTM & 65 & 146 & 0.48 & 0.78 & $\begin{array}{l}268 \\
12.5\end{array}$ & $\begin{array}{c}269 \\
11.0\end{array}$ & $\begin{array}{l}270 \\
3.3\end{array}$ & $\begin{array}{c}165 \\
18.9\end{array}$ & $\begin{array}{l}166 \\
100\end{array}$ & $\begin{array}{l}179 \\
10.5\end{array}$ & $\begin{array}{c}136 \\
13.9\end{array}$ & & $5.35 \mathrm{~s}$ & \\
\hline
\end{tabular}

TLC: silica gel $\mathrm{GF}_{254}$

$\mathrm{S}_{1}-\mathrm{BuOH}: \mathrm{H}_{2} \mathrm{O}=86: 14$

$\mathrm{S}_{2}-\mathrm{CHCl}_{3}: \mathrm{EtOH}=7: 3$

Abbreviated compounds: AMT2, 1,3-N,N-diallyloxymethylthymine; AMUTM, 1- $N$-allyloxymethyl-5,6-tetramethyleneuracil; DHPMU, 1-N-[(2',3'-dihydroxy-1'-propoxy)methyl]uracil; DHPMT1, 1-N-[(2',3'-dihydroxy-1'-propoxy)methyl]thymine; DHPMUDM, 1-N-[(2',3'-dixydroxy-1'-propoxy)methyl]-5,6-dekamethyleneuracil; DHPMUTM, 1$N$-[(2',3'-dihydroxy-1'-propoxy)methyl]-5,6-tetramethyleneuracil. 


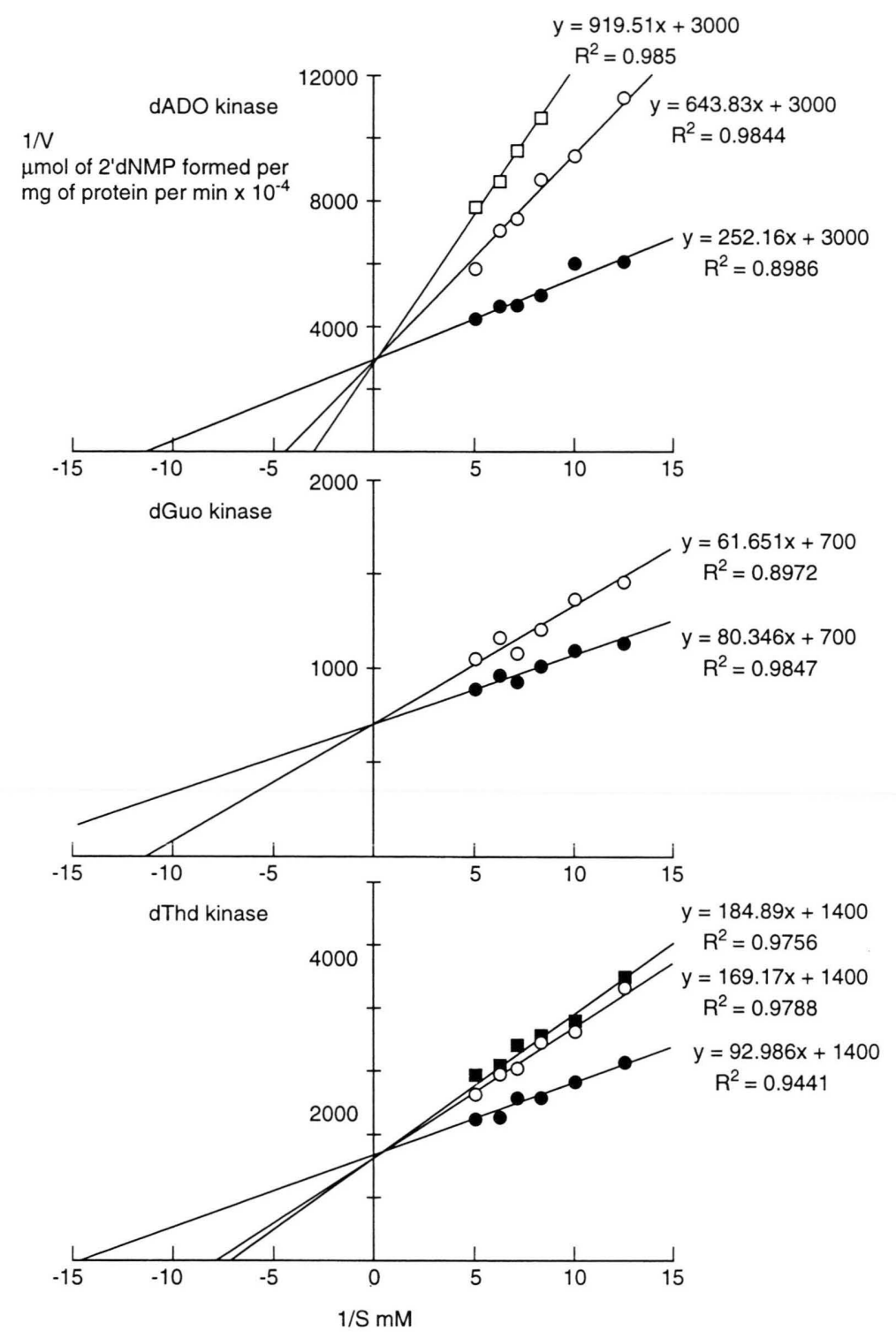

Fig. 2. Double reciprocal plots of the rate of dAdo, dGuo and dThd kinase activities in the cytosol of a 10-day

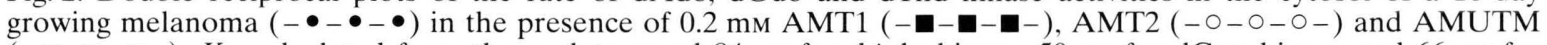
$(-\square-\square-\square-) . K_{\mathrm{m}}$ calculated from these plots equal $84 \mu \mathrm{m}$ for dAdo kinase, $50 \mu \mathrm{m}$ for dGuo kinase and $66 \mu \mathrm{m}$ for dThd kinase. $K_{\mathrm{i}}$ values presented in Table II calculated from $K_{\mathrm{mi}}$ values were obtained from these plots. y - regression equation; $\mathrm{R}^{2}>0.5$ indicates that points belonging to the straight line are in the set of this line data (according to Chem.Windows 3 statistical computer program). $K_{\mathrm{mi}}: K_{\mathrm{m}}$ constant in the presence of inhibitor.

Kirkman-Robbins hepatoma (AMU, DHPMT2, Modrzejewska et al., 1996), were entirely inactive in case of melanoma, while AMT2, being an AMT1 derivative, inhibited the phosphorylation of as many as three 2'dNs (dAdo, dGuo, dThd) in melanoma.
Kinetics of 2'dN kinases inhibition (Fig. 2, double-reciprocal plots of dAdo, dGuo and dThd kinase activities in presence of AMT1, AMT2 and AMUTM) indicates that the mentioned ACNs are competitive inhibitors of dAMP, dGMP and dTMP synthesis. As it will be demonstrated later, 
Table II. The influence of biologically active ACN's (AMT1, AMT2, AMUTM) on 2'dN kinase activities ( $\mu$ mol of 2 'dNMP formed per $\mathrm{mg}$ of protein per min. $\left.\times 10^{-4}\right)$ in cytosol of growing melanoma. In vitro -10 days after tumor transplantation in presence of respective ACN's $(0,2 \mathrm{~mm})$; in vivo - 10 days after tumor transplantation the animals were given ACN's ( $0.2 \mathrm{mmol}$ per $\mathrm{kg}$ of body weight) and 48 h later the enzyme activities were assayed. Control: 2 ' $\mathrm{dN}$ kinase activities in cytosol of 10 (experiments in vitro) or 12 days (experiments in vivo) old melanoma. Each value: the mean \pm SD for four separate experiments. NS-mean non significant (i.e. $p<0.05$ ); $p$ values, after checking variance conformability using Fisher-Snedecor test, were calculated using Student's t-test. In parentheses: \% of inhibition. The remaining ACN's presented in Fig. 1 have no influence on 2'dNMP synthesis in melanoma cells.

\begin{tabular}{|c|c|c|c|c|}
\hline in vitro & dAdo kinase & dGuo kinase & dCyd kinase & dThd kinase \\
\hline Control & $2.3 \pm 0.25$ & $11.2 \pm 0.93$ & $0.51 \pm 0.06$ & \multirow{5}{*}{$\begin{array}{l}5.4 \pm 0.51 \\
4.0 \pm 0.31 \\
\left(26 \%, \mathrm{p}=0.005, \mathrm{~K}_{\mathrm{i}}=188 \mu \mathrm{M}\right) \\
3.7 \pm 0.25 \\
\left(32 \%, \mathrm{p}=0.002, \mathrm{~K}_{\mathrm{i}}=212 \mu \mathrm{M}\right) \\
5.2 \pm 0.52\end{array}$} \\
\hline AMT1 & $2.2 \pm 0.22$ & $\begin{array}{c}9.4 \pm 0.80 \\
(12 \%, \text { NS })\end{array}$ & $0.48 \pm 0.05$ & \\
\hline AMT2 & $\begin{array}{l}1.5 \pm 0.13 \\
\left(35 \%, p=0.002, K_{i}=126 \mu \mathrm{M}\right)\end{array}$ & $\begin{array}{l}8.1 \pm 0.7 \\
\left(28 \%, p=0.002, \mathrm{~K}_{\mathrm{i}}=227 \mu \mathrm{M}\right)\end{array}$ & $\begin{array}{l}0.44 \pm 0.0 .05 \\
(14 \%, \mathrm{NS})\end{array}$ & \\
\hline AMUTM & $\begin{array}{l}1.3 \pm 0.12 \\
\left(44 \%, p=0.001, K_{i}=76 \mu \mathrm{M}\right)\end{array}$ & $11.4 \pm 0.092$ & $0.49 \pm 0.06$ & \\
\hline in vivo & & & & \\
\hline Control & $2.8 \pm 0.38$ & $10.8 \pm 0.86$ & $0.46 \pm 0.05$ & \multirow{4}{*}{$\begin{array}{l}6.2 \pm 0.62 \\
4.22 \pm 0.41 \\
(32 \%, p=0.001) \\
4.2 \pm 0.39 \\
(34 \%, p=0.001) \\
6.1 \pm 0.6\end{array}$} \\
\hline AMT1 & $3.0 \pm 0.3$ & $10.4 \pm 0.82$ & $\begin{array}{l}0.40 \pm 0.04 \\
(14 \%, \mathrm{NS})\end{array}$ & \\
\hline AMT2 & $\begin{array}{l}1.7 \pm 0.12 \\
(39 \%, p=0.001)\end{array}$ & $\begin{array}{l}7.5 \pm 0.71 \\
(31 \%, p=0.002)\end{array}$ & $0.48 \pm 0.07$ & \\
\hline AMUTM & $\begin{array}{l}1.6 \pm 0.11 \\
(43 \%, p=0.001)\end{array}$ & $11.3 \pm 0.9$ & $\begin{array}{l}0.39 \pm 0.04 \\
(16 \%, \mathrm{NS})\end{array}$ & \\
\hline
\end{tabular}

For abbreviations see Fig. 1.

the inhibitors of synthesis of the mentioned 2'd NMP are not AMT1, AMT2 and AMUTM but their triphosphates which are formed by $\mathrm{ACN}$ phosphorylation catalyzed by kinases present in the cytosol of the growing tumor. Table III demonstrates the phosphorylation of ACNs by kinases present in the cytosol of melanoma growing for 10 days. A $40 \mathrm{~min}$. incubation with cytosol (i.e. during 2'dN incubation time sufficient to determine 2'dN kinases) indicates that besides AMA and AMG all the remaining $12 \mathrm{ACNs}$ are phosphorylated to monophosphates; phosphorylation of AMU, AMUF, DHPMT2 and DHPMT2 phosphate is completed at the diphosphate stage, and only the biologically active ACNs (i.e. AMT1, AMT2 and AMUTM) are phosphorylated to triphosphates. Studying the kinetics of AMT1, AMT2 and AMUTM triphosphate formation we assume that the concentration of these phosphorylated derivatives increases until the $40^{\text {th }} \mathrm{min}$. of incubation, then it does not change for the following 30$40 \mathrm{~min}$. To confirm the fact that it is not AMT1, AMT2 and AMUTM but their triphosphates, which are the active species for inhibition of dAMP, dGMP and dTMP synthesis, an $80 \mathrm{~min}$. in- cubation time was applied in experiments to study the in vitro inhibition of 2'dNMP synthesis.

As it has been mentioned earlier (Modrzejewska et al., 1996) phosphorylation of the allyloxymethyl group in AMT1, AMT2 and AMUTM must be preceded by an enzymatic hydration of unsaturated bonds in vivo. Hydration of such bonds described by Jarvi et al. (1991) transforms the allyloxymethyl group into a 1-hydroxypropoxymethyl residue $\left(-\mathrm{CH}_{2}-\mathrm{O}-\mathrm{CH}_{2}-\mathrm{CH}_{2}-\mathrm{CH}_{2} \mathrm{OH}\right)$ or 2-hydroxypropoxymethyl residue $\left(-\mathrm{CH}_{2}-\mathrm{O}-\mathrm{CH}_{2}\right.$ $\mathrm{CHOH}-\mathrm{CH}_{3}$ ). Hydratases present in hepatoma (Modrzejewska et al., 1996) prefer the allyloxymethyl group bound to pyrimidines (thymine, uracil). This is similar to melanoma where neither AMA nor AMG underwent phosphorylation (Table III). It should be expected that phosphorylation of the appropriate ACNs relates to a $-\mathrm{CH}_{2} \mathrm{OH}$ group and not a - $\mathrm{CHOH}$ group as cellular kinases responsible for $\mathrm{ACN}$ phosphorylation prefer first order alcoholic groups (Bouffard et al., 1993; Salomon et al., 1995). It is suggested that the effect of melanoma hydratases on allyloxymethylopyrimidines leads to the formation of $-\mathrm{CH}_{2}-\mathrm{O}-\mathrm{CH}_{2}-\mathrm{CH}_{2}$ $\mathrm{CH}_{2} \mathrm{OH}$ groups in these ACNs. 
Table III. The phosphorylation of ACN's $(0.2 \mathrm{~mm})$ during a 40 -min incubation by kinases present in the cytosol of a 10-day growing melanoma ( $\mu$ mol of $\left[{ }^{32} \mathrm{P}\right] \mathrm{ACN}$ mono, di and triphosphate formed per mg of protein per min. $\times$ $\left.10^{-4}\right)$. In parentheses: \% of phosphorylation.

\begin{tabular}{|c|c|c|c|}
\hline $\mathrm{ACN}$ & {$\left[{ }^{32} \mathrm{P}\right]$ ACN monophosphate } & {$\left[{ }^{32} \mathrm{P}\right] \mathrm{ACN}$ diphosphate } & {$\left[{ }^{32} \mathrm{P}\right]$ ACN triphosphate } \\
\hline & \multicolumn{3}{|c|}{ Thymine derivatives } \\
\hline $\begin{array}{l}\text { AMT1 } \\
\text { AMT2 } \\
\text { DHPMT1 } \\
\text { DHPMT2 } \\
\text { DHPMT2 phosphate } \\
\text { PMT }\end{array}$ & $\begin{array}{l}1.4 \pm 0.2 \\
1.2 \pm 0.16 \\
2.3 \pm 0.3 \\
3.6 \pm 0.4 \\
0.0 \\
0.0\end{array}$ & $\begin{array}{l}0.11+0.02(6.8 \%) \\
0.1+0.05(7.2 \%) \\
0.0 \\
0.87 \pm 0.13(19.5 \%) \\
3.2 \pm 0.4(99.5 \%) \\
0.0\end{array}$ & $\begin{array}{l}0.088 \pm 0.011(5.5 \%) \\
0.09 \pm 0.013(6.8 \%) \\
0.0 \\
0.0 \\
0.017 \pm 0.002(0.5 \%) \\
0.0\end{array}$ \\
\hline PMT & \multicolumn{3}{|c|}{ Uracil derivatives } \\
\hline $\begin{array}{l}\text { AMU } \\
\text { DHPMU } \\
\text { AMUTM } \\
\text { DHPMUTM } \\
\text { AMUF } \\
\text { DHPMUDM }\end{array}$ & $\begin{array}{l}0.95 \pm 0.12 \\
0.3 \pm 0.16 \\
1.6 \pm 0.2 \\
1.2 \pm 0.15 \\
0.9 \pm 0.13 \\
0.0\end{array}$ & $\begin{array}{l}0.88 \pm 0.1(48 \%) \\
0.1 \pm 0.012(7.2 \%) \\
0.14 \pm 0.018(7.7 \%) \\
0.09 \pm 0.013(7.5 \%) \\
0.04 \pm 0.006(4.3 \%) \\
0.0\end{array}$ & $\begin{array}{l}0.005 \pm 0.0007(0.3 \%) \\
0.0 \\
0.12 \pm 0.015(6.6 \%) \\
0.0 \\
0.0\end{array}$ \\
\hline DHPMUDM & \multicolumn{3}{|c|}{ Purine derivatives } \\
\hline $\begin{array}{l}\text { AMA } \\
\text { AMG }\end{array}$ & $\begin{array}{l}0.0 \\
0.0\end{array}$ & $\begin{array}{l}0.0 \\
0.0\end{array}$ & $\begin{array}{l}0.0 \\
0.0\end{array}$ \\
\hline
\end{tabular}

Abbreviated compounds: AMT1, 1- $N$-allyloxymethylthymine; AMT2, 1,3- $N, N$-diallyloxymethylthymine; DHPMT1, $1-N$-[(2',3'-dihydroxy-1'-propoxy)methyl]thymine; DHPMT2, 1-N-[(1',3'-dihydroxy-2'-propoxy)methyl]thymine; PMT, 1-N-propoxymethylthymine; AMU, 1- $N$-allyloxymethyluracil; DHPMU, 1- $N$-[(2',3'-dihydroxy-1'-propoxy)methyl]uracil; AMUTM, 1- $N$-allyloxymethyl-5,6-tetramethyleneuracil; DHPMUTM, 1- $N$-[(2',3'-dihydroxy-1'-propoxy)methyl]-5,6-tetramethyleneuracil; DHPMUDM, 1- $N$-[(2',3'-dihydroxy-1'-propoxy)methyl]-5,6-dekamethyleneuracil; AMUF, 1-N-allyloxymethyl-5-fluorouracil; AMA, 9- $N$-allyloxymethyladenine; AMG, 9- $N$ allyloxymethylguanine.

A common feature of ACNs which are not phosphorylated to triphosphates in vivo is the presence of a chiral carbon atom in the synthon (Compounds: III,IV, V, VIII, X, XI - Table III)). Lack of PMT phosphorylation follows from the fact that the hydroxypropoxymethyl group constituting the synthon in PMT does not undergo hydration (Modrzejewska et al., 1996). Lack of AMU, DHPMT2 and DHPMT2 phosphate triphosphates (and in consequence lack of their biological activity) results from a high concentration of these ACNs diphosphates (Table III) which are inhibitors of triphosphates synthesis in vivo (Krenitsky et al., 1990).

AMUF is the only ACN whose lack of phosphorylation to a triphosphate is difficult to interpret. The presence of fluorine atom at position 5 of the pyrimidine chain does not seem to be decisive about the absence of phosphorylation as there are very many 5-fluoronucleosides and nucleotides which are phosphorylated in vivo to corresponding triphosphates (Sato et al., 1993; Willmore and Durkacz, 1993).

Table IV shows the distribution of $\left[{ }^{14} \mathrm{C}\right] 2$ 'dN, $\left[{ }^{14} \mathrm{C}\right] \mathrm{ACN}$ and $\left[{ }^{14} \mathrm{C}\right] 2 \mathrm{dN}$ in the presence of $\mathrm{ACN}$ between DNA and cytosol in 10 days growing melanoma. Incorporation of $\left[{ }^{14} \mathrm{C}\right] 2 \mathrm{dN},\left[{ }^{14} \mathrm{C}\right] \mathrm{ACN}$ and $\left[{ }^{14} \mathrm{C}\right] 2$ 'dN with $\mathrm{ACN}$ present into tumor DNA indicates that all $\left[{ }^{14} \mathrm{C}\right] 2$ 'dNs are incorporated into DNA (average incorporation of all $\left[{ }^{14} \mathrm{C}\right] 2$ 'dNs : $88.7 \pm 1.7 \%$ ), whereas practically none of $\left[{ }^{14} \mathrm{C}\right]$ ACNs is incorporated into DNA (incorporation mean of $\left[{ }^{14} \mathrm{C}\right] \mathrm{ACN}: 0.66 \pm 0.0015 \%, 2$ 'dN/ACN incorporation ratio: 1344$)$. Biologically active ACNs significantly diminish incorporation of $\left[{ }^{14} \mathrm{C}\right] 2$ 'dN into DNA. AMT1 reduces incorporation of dThd from $32.2 \mathrm{nmol}$ to $8.73 \mathrm{nmol}$ per $\mathrm{mg}$ of DNA (i.e. reduction by $73 \%$ ), AMT2 inhibits incorporation of dAdo from $21 \mathrm{nmol}$ to $6.2 \mathrm{nmol}$ per $\mathrm{mg}$ of DNA (i.e. reduction by $70 \%$ ), dGuo from $34.2 \mathrm{nmol}$ to $15.4 \mathrm{nmol}$ per mg of DNA (i.e. reduction by $53 \%$ ) and dThd from $32.2 \mathrm{nmol}$ to $11 \mathrm{~nm}$ per $\mathrm{mg}$ of DNA 
Table IV. Distribution of $\left[{ }^{14} \mathrm{C}\right]$ 2'dNs, $\left[{ }^{14} \mathrm{C}\right]$ AMT1, $\left[{ }^{14} \mathrm{C}\right]$ AMT2 and $\left[{ }^{14} \mathrm{C}\right]$ AMUTM (A) and $\left[{ }^{14} \mathrm{C}\right] 2$ 'dNs in the presence of AMT1, AMT2 and AMUTM (B) between DNA and cytosol in a 10-day growing melanoma $48 \mathrm{~h}$ after administration of the compounds. Animals were given $0.2 \mathrm{mmol}\left[{ }^{14} \mathrm{C}\right] 2 \mathrm{dNs}, 4 \times 10^{6} \mathrm{cpm}(0.066 \mathrm{MBq})$ or $0.2 \mathrm{mmol}$ $\left[{ }^{14} \mathrm{C}\right] \mathrm{ACN}, 3 \times 10^{5} \mathrm{cpm}(0.005 \mathrm{MBq})$ per kg of body weight $(\mathrm{A})$ or $\left[{ }^{14} \mathrm{C}\right] 2$ 'dNs (labeled as above) with biologically active $\mathrm{ACN}$ (in doses as in $\mathrm{A}$ ). The incorporation was expressed in nmol of $\left[{ }^{14} \mathrm{C}\right]$ compounds per mg of DNA or nmol per mg of protein (cytosol) Each value: the mean \pm SD for four separate experiments. In parentheses: \% of incorporation.

\begin{tabular}{lllllllll}
\hline & \multicolumn{2}{c}{ A } & \multicolumn{2}{c}{ AMT1 } & \multicolumn{2}{c}{ B } & & \multicolumn{2}{c}{ AMT2 } & AMUTM \\
& DNA & Cytosol & DNA & Cytosol & DNA & Cytosol & DNA & Cytosol \\
\hline dAdo & $21 \pm 1.8(86)$ & $3.24 \pm 0.3(14)$ & $17.8 \pm 1.6(85)$ & $3.1 \pm 0.3(15)$ & $6.21 \pm 0.7(31)$ & $13.7 \pm 0.9(69)$ & $7.3 \pm 0.8(28)$ & $19 \pm 2.6(72)$ \\
dGuo & $34.2 \pm 4.9(85)$ & $5.94 \pm 0.7(15)$ & $40 \pm 5.4(93)$ & $3 \pm 0.3(7)$ & $15.4 \pm 1.6(38)$ & $25 \pm 2.6(62)$ & $35.5 \pm 6.5(90)$ & $3.6 \pm 0.5(10)$ \\
dCyd & $12.6 \pm 0.9(89)$ & $1.62 \pm 0.17(11)$ & $11.7 \pm 1.6(87)$ & $1.8 \pm 0.2(13)$ & $11 \pm 0.9(89)$ & $1.26 \pm 0.17(11)$ & $12.6 \pm 1.5(86)$ & $2 \pm 0.3(14)$ \\
dThd & $32.2 \pm 5.3(90)$ & $3.28 \pm 0.4(10)$ & $8.73 \pm 0.9(29)$ & $21 \pm 2.8(71)$ & $12 \pm 1.5(34)$ & $23.4 \pm 2.7(66)$ & $28.8 \pm 4.5(94)$ & $1.8 \pm 0.2(6)$ \\
AMT1 & $1.2 \pm 0.3(3)$ & $38.4 \pm 3.4(97)$ & - & - & - & - & - & - \\
AMT2 & $1.4 \pm 0.4(3)$ & $43.2 \pm 4.7(97)$ & - & - & - & - & - & - \\
AMUTM & $1.7 \pm 0.4(4)$ & $41 \pm 4.2(96)$ & - & - & - & - & - & - \\
\hline
\end{tabular}

Abbreviated ACNs: AMT1, 1- $N$-allyloxymethylthymine; AMT2, 1,3-N,N-diallyloxymethylthymine; AMUTM, 1- $N$-allyloxymethyl-5,6tetramethyleneuracil.

(i.e. reduction by $64 \%$ ). AMUTM, similarly, reduces dAdo incorporation from $21 \mathrm{nmol}$ to $7.3 \mathrm{nmol}$ (i.e. reduction by $66 \%$ ). Quantitatively, the results do not correlate with the decrease of activities of 2'dN kinases by the mentioned ACNs. AMT1 reduces (in vivo) the activity of dThd kinase by $32 \%$ (Table II), but the same ACN inhibits dThd incorporation (in fact dTTP) into DNA by $70 \%$, as this amount of dThd remains in cytosol in experiments with the use of $\left[{ }^{14} \mathrm{C}\right]$ dThd with AMT1 (Table IV). Similarly, in case of $\left[{ }^{14} \mathrm{C}\right] \mathrm{dAdo}$, $\left[{ }^{14} \mathrm{C}\right] \mathrm{dGuo}$ and $\left[{ }^{14} \mathrm{C}\right] \mathrm{dThd}$, inhibition of incorporation of these $\left[{ }^{14} \mathrm{C}\right] 2$ 'dNs (phosphorylated in vivo to dATP, dGTP, and dTTP) by AMT2 and AMUTM, is always twice as high as the inhibition of activity of corresponding 2' $\mathrm{dN}$ kinases (Table IV). It is concluded that AMT1, AMT2 and AMUTM, beside inhibiting 2' dN kinases activities, are also inhibitors of DNA polymerase. Such inhibition of acyclonucleosides triphosphates, modified nucleosides and nucleotides has been reported (Derse et al., 1981; Martin et al., 1994; Ilsley et al., 1995). Apparently the cytostatic activity of
AMT1, AMT2 and AMUTM is of synergistic character: inhibiting the activity of 2' $\mathrm{dN}$ kinases it causes a reduction of substrates concentration for DNA polymerase, and, concurrently, inhibits DNA polymerase activity. Presumably, the latter inhibition occurs via a competition of AMT1, AMT2 and AMUTM triphosphates with natural substrates of DNA polymerase (dATP, dGTP, dTTP). The expected inhibition of pyrimidine nucleoside phosphorylase activity by biologically active ACNs (Modrzejewska et al., 1996) has been confirmed for thymidine phosphorylase which is inhibited by AMT1 in human neoplasm (Miszczak-Zaborska et al., 1997).

Because phosphorylases present in the tumor exhibit preferences to modify ribo- and 2'deoxynucleosides (Savarese et al., 1981) this additional effect of allyloxymethylopyrimidine, by augmenting $\mathrm{ACN}$ concentration in tissues concurrently intensifies the cytostatic effect of ACN. The results on allyloxymethyl derivatives of thymine and uracil, confirming their cytostatic properties encourage further studies on these acyclonucleosides. 
Blin N. and Stafford D. W. (1976), General methods for isolation of high molecular weight DNA from eukaryotes. Nucl. Acid Res. 3, 2303-2308.

Bouffard D. Y., Laliberte J. and Momparler R. L. (1993), Kinetic studies on 2,2'difluorodeoxycytidine (gencitabine) with purified human deoxycytidine kinase and cytidine deaminase. Biochem. Pharmacol. 45, 18571861.

Bradford M. (1976), A rapid and sensitive method for the quantitation of microgram quantities of protein utilizing the principle of protein-dye binding. Anal. Biochem. 72, 248-254.

Bomirski A., Słomiński A. and Bigda J. (1998), The natural history of a family of transplantable melanomas in hamsters. Canc. Metastasis Rev. 7, 95-118.

Derse D., Cheng Y-C, Furman P. A., St. Clair M. H. and Elion G. B. (1981), Inhibition of purified human and herpes simplex virus induced DNA polymerase by a 9(2-hydroxyethoxymethyl) guanine triphosphate. Effect on primer template function. J. Biol. Chem. 256, $11447-11451$.

Drabikowska A. K., Lissowska L., Dramiński M., ZgitWróblewska A. and Shugar D. (1987), Acyclonucleoside analogues consisting of 5- and 5,6- substituted uracil and different acyclic chains: inhibitory properties versus E.coli uridine phosphorylase. Z. Naturforsch. 42 c, 288-296.

Dramiński M. and Frass E. (1981), Alkylated derivatives of uracil. Part IX. Synthesis of N-(2, 3'-dihydroxypropyl) derivatives of 5,6-tetramethyleneuracil. Pol. J. Chem. 55, 1547-1552.

ElAshry E. S. H. and ElKilany Y. (1997), Acyclonucleosides. Part 2: diseconucleosides. Adv. Heterocyclic Chem. 68, $1-88$.

Greger J. and Dramiński M. (1989), Growth inhibition of Kirkman-Robbins hepatoma by $1(1,3$ '-dihydroxy2'-propoxymethyl) 5,6 tetramethylene uracil and possible mechanism of its biological activity. Z. Naturforsch. 44c, 985-991.

Ilsley D. D., Lee S-H., Miller W. H. and Kuchta R. P. (1995), Acyclic guanosine analogs inhibit DNA polymerase $\alpha, \beta$ and $э$ with very different potentation and have unique mechanism of action. Biochemistry 34 , 2504-2510.

Jarvi E. T., Mc Carthy J. R., Mehdi S., Matthews D. P., Edwards M. L., Prakash N. J., Bowlin T. L., Sunkara P. S. and Bey P. (1991), 4'5'unsaturated 5 halogenated nucleosides. Mechanism based and competitive inhibitors of S-adenosyl-L-homocysteine hydrolase. J. Med. Chem. 34, 647-656.

Krenitsky T. A., Tuttle J. V., Miller W. H., Moorman A. R., Orr G. F. and Beauchamp L. (1990), Nucleotide analogue inhibitors of purine nucleoside phosphorylase. J. Biol. Chem. 265, 3066-3069.
Martin J. L., Brown C. E., Matthews-Davis N. and Reardon J. E. (1994), Effect of antiviral nucleoside analogs on human DNA polymerase and mitochondrial DNA synthesis. Antimicrob. Agents Chemother. 38, 27432749.

Miszczak-Zaborska E., Greger J., Woźniak K., Kowalska Koprek U. and Pajszczyk-Kieszkiewicz T. (1997), The activity of thymidine phosphorylase in the uterine myomas and the myometrium in perimenopausal women. Z.Naturforsch. 52c, 850-854.

Modrzejewska H. Greger J, Lewandowska U, Fidek W. (1994), In vivo phosphorylation of allyloxymethyl purine and pyrimidine acyclonucleosides and the inhibitory effect of these compounds on thymidine and deoxyguanosine kinases. Acta Biochim. Pol. 41, $185-187$.

Modrzejewska H., Greger J., Dramiński M., Rutkowski M. (1996), The influence of alkoxymethyl purine and pyrimidine acyclonucleosides on growth inhibition of Kirkman-Robbins hepatoma and possible mechanism of their cytostatic activity Z. Naturforsch. 51c, 75-80.

Ozierov A. A., Novkov M. C., Brel A. K., Andrejeva O. T., Vladyko G. V., Boreko E. I., Korbachenko L. Y. and Vervetchenko C. G. (1991), The synthesis and antiviral activity of newly synthesized unsaturated pyrimidine acyclonucleosides Chim. Pharm. 25, 44-47.

Salomon B., Maury S., Loubiére L., Caruso M., Onclerq R. and Klatzman D. (1995), A truncated herpes simplex virus thymidine kinase phosphorylates thymidine and nucleoside analogs and does not cause sterility in transgenic mice. Mol. Cell. Biol. 15, 5322-5328.

Sato S., Kohno K., Hidaka K., Hisatsungu T., Kuwano M. and Komiyama S. (1993), Differentially potentiating effects by dipyridamole on cytotoxicity of 5-fluorouracil against the human maxillary cancer cell lines derived from a single tumor. Anti Canc. Drug Design 8, 289-297.

Savarese G. W., Crabtree G. M. and Parks Jr R. E. (1981), 5'-methylthioadenosine phosphorylase. Substrate activity of 5'-deoxyadenosine with the enzyme from Sarcoma 180 cells. Biochem. Pharmacol. 30, $189-199$.

Słomiński A. and Paus R. (1993), Bomirski melanomas: a versatile and powerful model for pigment cells and melanoma research. Int. J. Oncol. 2, 221-228.

Thormar H., Georgsson G., Gunnarssson E., Naesens L., Torsteins S., Balzarini J. and De Clerg E. (1998), Treatment of visna virus infection in lambs with acyclic nucleoside phosphonate analogue 9-(2-phoshonylmethoxyethyl)adenine. Antiviral Chem. Chemother. 9, 245-252.

Willmore E. and Durkacz B. (1993), Cytotoxic mechanism of 5'-fluoropyrimidines. Biochem. Pharmacol. 46, 205-211. 